\title{
Construction of Computer Training Course System for Higher Vocational Marketing Specialty under the Background of Internet
}

\author{
Xiaoyun Duan ${ }^{1}$ Xingyu $\mathrm{Li}^{2}$ Song Zhao ${ }^{3}$ \\ 1,2,3 Jiangxi Tourism\&Commerce Vocational College, Nanchang, Jiangxi, 330000, China
}

\begin{abstract}
Under the background of "Internet ", e-commerce and network marketing have developed rapidly, and the students of marketing major in various industries also have higher requirements, so colleges and universities need to pay attention to the cultivation of marketing students. Because computer plays a great role in marketing, the marketing specialty in higher vocational colleges needs to be brought into the computer training course system to realize the construction of the computer course training system of higher vocational marketing specialty. This paper gives a brief overview of marketing major, analyzes the needs of computer knowledge and curriculum in higher vocational marketing major, and studies the construction path of computer training course system in higher vocational marketing major. Finally, the problems existing in the construction of computer training courses in higher vocational marketing specialty and their solutions are analyzed.
\end{abstract}

\section{Introduction}

Nowadays, the marketing major in higher vocational colleges pays more and more attention to the improvement of students' computer skills, because the application ability of computer is the main factor for the students of higher vocational marketing major to change and act on the marketing mode. Therefore, computer is playing an important role in higher vocational marketing major. Therefore, improving the computer operation skills of marketing students is the key to the success of graduates in the future.

\section{Overview of Marketing Specialty}

To put it simply, marketing is a business administration major, which is based on economics, management and modern information technology. Marketing is a discipline that explores how to meet customer needs and the laws of market demand. This major can cultivate professional talents with humanistic spirit, scientific accomplishment and professional knowledge and skills. Therefore, learning marketing specialty needs to have certain innovative entrepreneurial thinking, as well as the ability of analysis and observation, to train applied talents who can solve practical problems[1].

Marketing major general repair years for four years, can not be less than three years. Students need to master mathematics, statistics, economics and other professional knowledge, and can use appropriate methods, through the search for literature to acquire knowledge, good at absorbing the knowledge and experience of others, so as to build their own knowledge system. Need to have the ability to analyze and solve practical problems, at the same time need to have certain innovative thinking, critical thinking, learn to use professional knowledge to constantly innovate practice. At the same time, students majoring in marketing need to have good ideological and moral quality, professional quality, cultural quality and so on.

Nowadays, the teachers of marketing major in higher vocational colleges in China are expanding and need to hire professional teachers. At the same time, teachers need to have certain innovative practical ability, noble professional ethics, and higher teaching level. The most important thing is to have certain practical experience in order to impart practical teaching knowledge to students, so as to cultivate professional talents with strong practical ability.

At present, higher vocational colleges in China can learn from foreign experience and pay attention to the cultivation of students' ability in planning, writing, analysis and communication. Cooperate with outside enterprises[2], arrange students to enter enterprise practice, learn practical experience, and train professional talents with major enterprises. Teachers can also lead students into the enterprise, into the society, to complete a more practical subject, for the study of marketing graduates can be better qualified for the job. At the same time, the employment direction of learning marketing major is also more extensive. Graduates can try to engage in related marketing positions in institutions and government departments, or engage in market research and market planning in major enterprises. Sales management, etc.

Of course, when training students majoring in marketing, colleges and universities can make full use of

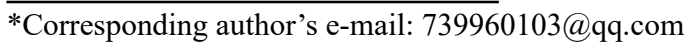


modern computer network, realize efficient teaching and learning, construct a certain computer training course system, and change the traditional marketing teaching method. In order to realize the construction of computer training course system of higher vocational marketing specialty.

\section{Analysis of Computer Knowledge Demand and Curriculum Demand in Higher Vocational Marketing Specialty}

\subsection{Requirements of Computer Knowledge for Students in Higher Vocational Marketing Specialty}

At present, the marketing major of higher vocational colleges in China is mainly aimed at training industry, agriculture, e-commerce and so on. Therefore, students need to have certain professional knowledge of management, calculation, statistics, writing and so on. Of course, students majoring in marketing need to have some basic knowledge of market research, product sales and marketing management, as well as some professional abilities such as product sales, sales team management and marketing planning. In order to develop skilled basic work, and marketing management ability of high-quality professional and technical personnel.

At present, the training goal of higher vocational marketing specialty in our country is mainly to assess the basic knowledge of marketing specialty, and also to have the professional skills of collecting, analyzing and processing information. These need to be applied to computer professional theoretical knowledge, especially familiar with marketing financial accounting and management skills, need to master all kinds of computer office software. With the rapid development of computer network, a large number of innovative sales talents are also needed in the market at present. However, the source of these talents needs the attention of marketing majors in colleges and universities in China. Cultivate high-quality practical ability of marketing professionals, in the future in their own posts.

\subsection{Marketing graduates' demand for computer knowledge in future positions}

At present, according to the post analysis of marketing major in higher vocational colleges in China, it can be concluded that students engaged in marketing positions have higher requirements for mastering computer knowledge. In the recruitment of marketing posts, the major enterprises have clear regulations on the degree of computer mastery. It can be seen that students' computer knowledge and skills are particularly important in marketing posts. Therefore, colleges and universities need to focus on training the computer operation skills of marketing students[3], improve the computer level of students in all directions, and lay a solid foundation for future employment. The following table is about the job distribution of marketing majors in higher vocational colleges.

TABle 1 The Job Distribution Of Marketing Majors In Higher Vocational COLlEges

\begin{tabular}{|c|c|c|c|c|}
\hline $\begin{array}{l}\text { employment } \\
\text { position }\end{array}$ & $\begin{array}{l}0 \% \sim \\
25 \%\end{array}$ & $\begin{array}{c}25 \% \sim \\
50 \%\end{array}$ & $\begin{array}{c}50 \% \sim \\
75 \%\end{array}$ & $\begin{array}{l}75 \% \sim \\
100 \%\end{array}$ \\
\hline $\begin{array}{l}\text { employment } \\
\text { position }\end{array}$ & & & & \\
\hline $\begin{array}{c}\text { commercial } \\
\text { traveller }\end{array}$ & $\sqrt{ }$ & & & \\
\hline $\begin{array}{l}\text { After-sales } \\
\text { maintenance }\end{array}$ & $\sqrt{ }$ & & & \\
\hline $\begin{array}{c}\text { Business Public } \\
\text { Relations }\end{array}$ & & & $\sqrt{ }$ & \\
\hline $\begin{array}{c}\text { Product } \\
\text { Consultants }\end{array}$ & & & $\sqrt{ }$ & \\
\hline $\begin{array}{c}\text { Client } \\
\text { Commissioners }\end{array}$ & & $\sqrt{ }$ & & \\
\hline $\begin{array}{c}\text { Planning of } \\
\text { Internal Services }\end{array}$ & & & & \\
\hline $\begin{array}{c}\text { Service } \\
\text { Promotion }\end{array}$ & & & $\sqrt{ }$ & \\
\hline Market researcher & & & & $\sqrt{ }$ \\
\hline
\end{tabular}

It is not difficult to see from the table that the employment of marketing students is mostly engaged in product consultants, business public relations, service promotion and market research. Most of these work can not be separated from the use of computers, so it is very necessary for college students majoring in marketing to set up computer training courses[4].

\subsection{Analysis Analysis of Computer Course Setting in Higher Vocational Marketing Specialty}

Nowadays, with the rapid development of retail market, micro-business and various network marketing gradually appear, marketing also depends more and more on the network, therefore, the marketing major of each university also needs to learn certain computer technology. It has become an inevitable choice to bring computer training course into marketing specialty, which is the basis of constructing computer training course system. According to the above table, it is easy to observe that most of the students majoring in marketing need to use computers in the industries after graduation. Therefore, the students' proficiency in computer skills largely determines the direction of future work. Many students engaged in basic sales work, their computer skills are often not good enough, students engaged in sales management industry, their computer level is often high. Students with stronger computer skills can develop better in future jobs. Therefore, it is very necessary for colleges and universities to set up computer training course system. 


\section{The Construction Path of Computer Training Course System in Higher Vocational Marketing Specialty}

\subsection{Increase in elementary computer basic courses}

In order to realize the construction of computer training course system for higher vocational marketing specialty, it is necessary to add primary computer basic courses, such as some computer basic courses, network basic courses, office basic courses, and database basic courses. Before realizing the construction of computer training course system, it is necessary to cultivate students' basic skills of computer base, so as to lay a solid foundation for deeper computer teaching. In the study of computer basic courses, most of the basic knowledge is very simple for the students in higher vocational colleges. Therefore, teachers need to prevent the phenomenon of laziness and non-attendance due to complacency. At the same time, teachers also need to inculcate the importance of computer courses in marketing majors[5].

\subsection{Course on Applied Computer Skills}

Because computer plays an important role in marketing major, it is necessary to master certain applied computer skills in addition to learning primary computer basic courses. Therefore, higher vocational colleges need to set up computer application courses, such as computer maintenance course, computer application course, CAD drawing course and so on. Therefore, the graduates of higher vocational marketing major can manage the administrative affairs, human capital and financial marketing affairs of enterprises by using computer system. You can also use web design and network programming to process pictures, you can also use computer skills to publish information on the websites of major enterprises, and you can also maintain the daily software and hardware of computers. This also has certain safeguard to the enterprise network security. Therefore, higher vocational colleges need to train marketing professionals with strong comprehensive quality to adapt to the rapid development of enterprises.

\subsection{Building Computer Course Groups}

Computer classes have many courses, such as computer maintenance courses, application courses, CAD drawing mentioned above. Although the teaching content of each course is different, the computer theory and basic skills applied are the same. Therefore, the computer training course system of marketing specialty can be realized by establishing a complete course group. The curriculum group is to complete the design and teaching of the relevant courses in the field of computer by organizing the relevant teachers of computer major and forming teaching resultant force in teaching design, content arrangement, program design and so on.

\section{Problems and Solutions in the Construction of Computer Training Course for Higher Vocational Marketing Specialty}

\subsection{Weak teachers}

At present, the teaching level of marketing teachers in higher vocational colleges is generally high, but there are few professional teachers. Most teachers can master the professional knowledge of marketing, but lack practical experience. And the computer professional knowledge is not deep enough, it is difficult to connect the marketing major with the computer course, and it is difficult to enlighten the students' innovative thinking. Therefore, the weakness of teachers is one of the main problems in computer training courses in higher vocational marketing major. Higher vocational colleges need to strengthen the practical experience of professional teachers, can choose to cooperate with enterprises, organize teachers to learn practical experience in enterprises, help teachers to master practical skills in the teaching process, Improve students' practical skills, cultivate marketing students' innovative thinking, and realize the construction of computer training courses in higher vocational marketing.

\subsection{Students don't pay enough attention to computer courses}

The students of marketing major in higher vocational colleges attach importance to the study of their own professional knowledge, but lack a certain understanding of the study of computer courses. Marketing students have not yet realized the importance of computer information technology, which leads students to take computer courses with an indifferent attitude, turn a blind eye to the learning tasks assigned by teachers, and the examination is a mere formality. Therefore, the computer scores of marketing students are often low and the computer operation level is not skilled enough. Students treat the course with a free, loose mentality, it is difficult to improve the level of computer operation. Therefore, students' lack of attention to computer courses is one of the important problems in the construction of computer training courses in higher vocational marketing majors. Teachers need to correct students' attitude, explain to students the important role of computer in future employment, and prevent students from learning attitude of news.

\subsection{The level of curriculum objectives is not strong}

It is mentioned above that it is necessary to strengthen the construction of teachers in higher vocational colleges and correct the students' learning attitude, but the target level of marketing courses in higher vocational colleges is not obvious enough. Students do not understand the true use of knowledge, easy to lead to students lose 
motivation and confidence. Therefore, the low level of curriculum objectives is also the main problem in the construction of computer training courses in higher vocational marketing majors. In order to successfully realize the construction of computer training course system of marketing specialty [6], each higher vocational college should make clear the level of curriculum goal, let students understand the use of this professional knowledge and let students know how to use it.

\section{CONCLUSION}

In a word, with the development of network information technology, higher vocational marketing major is also facing great challenges. Therefore, the cultivation of comprehensive quality of marketing professionals is the most important. The application ability of computer is the key to the development of marketing students in the future, so it is very important to improve the computer application ability of marketing students. It is necessary to add basic computer courses and applied computer courses to help students be better qualified for future work. At the same time, it is necessary to strengthen the construction of teachers in higher vocational colleges, construct the computer training course system of marketing specialty, and cultivate high quality professionals with innovative consciousness.

\section{References}

1. Wu, J.C.Li, X.Q.(2019)Construction of Computer Training Course System for Higher Vocational Marketing Specialty[J].Guangxi Vocational and Technical College.

2. Xiong, W.(2016)Research on the Construction of Curriculum System for Higher Vocational Marketing Specialty in Industry Background[J].Agricultural University Of Hunan.

3. Yi, L.(2017)Research on Employment Competitiveness of Higher Vocational Marketing Graduates[J].Qufu Normal University.

4. Zhang, R.(2020)Discussion on Teaching Present Situation and Suggestions of Marketing Specialty in Higher Vocational College[J].Sichuan Modern Vocational College.

5. Cao, W.(2019)Teaching Research of Marketing in Computer Major of Secondary Vocational School[J].Jiaxing Xiushui Secondary Professional School.

6. Lu, K.M.(2017)Research on the Cultivation of Vocational Ability of Students in Higher Vocational Colleges[J].Jiangxi Normal University of Science and Technology. 